\title{
АВТОМАТИЗАЦІЯ ПРОЦЕСІВ ПЕРЕРОБКИ ВТОРИННОЇ СИРОВИНИ ВИНОРОБСТВА
}

\author{
Муратов В.Г. ${ }^{1}$, Левінський В.М. ${ }^{2}$, Осипова Л.А. ${ }^{3}$, Осипов В.Н. ${ }^{4}$ \\ 1,2,3 - Одеська національна академія харчових технологій \\ ${ }^{4}$ - Інститут проблем ринку і економіко-екологічних досліджень НАН України \\ ORCID: ${ }^{1}$ 0000-002-4196-7248 \\ E-mail: ${ }^{1}$ vikgorge@ukr.net
}

Copyright (C) 2018 by author and the journal “Automation technologies and business - processes. This work is licensed under the Creative Commons Attribution International License (CC BY). http://creativecommons.org/licanses/by/4.0

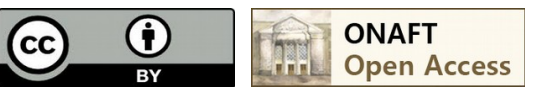

DOI: $10.15673 /$ atbp.v10i4.1227

Анотація: В статті розглядаються результати праці над грантовим проектом ЄС № 83263440 «Розвиток українсько-молдавського транскордонного виробничо-науково-освітнього кластера з переробки вторинних продуктів виноробства». Роботи направлені на зниження собівартості виноробної продукції за рахунок комплексної переробки вторинної сировини, що дає можливість одержувати продукти, які представляють значну цінність для низки галузей народного господарства, а саме: етиловий спирт, винну кислоту, енотанин, виноградне масло, біоконцентрати вітамінів групи $B$, вітамін $D$, фуражні корми, абразивні матеріали та інші. Представлена раціональна для Одеського регіону технологічна схема переробки, яка включає нові зразки обладнання - сепаратор, дробарку, інфрачервону сушарку. Способи термообробки сировини та конструкції обладнання захищені патентами України. Згідно із запропонованими способами термообробки сушарка ИКС-1 забезпечує інфрачервоне нагрівання насіння винограду з його наступним адіабатичним охолодженням-дозріванням. Приведена конструктивна схема сушарки. Також розглядається технічна реалізація системи автоматичного керування інфрачервоною сушаркою, в середовищі Simulink програми Matlab досліджені алгоритми регулювання, що забезпечують високу точність підтримання температури насіння в процесі сушіння. Представлена модель сушарки як об'єкту керування, запропонована структура системи, яка дозволяє частково компенсувати вплив на температуру насіння зовнішніх неконтрольованих збурень. Приведені порівняльні результати моделювання систем автоматичного регулювання звичайної і підвищеної динамічної точності, які підтвердили доцільність включення в систему додаткового каналу компенсації впливу збурень. Наведені результати промислових випробувань устаткування та систем автоматизації. Виявлені раціональні параметри технологічного процесу сушіння виноградного насіння. Випробовування підтвердили заявлені характеристики розроблених систем автоматизації і устаткування.

Abstract: In this article working results on EU grant project № 83263440 “The development of Ukrainian-Moldavian cross-border production-scientific-educational cluster on the processing of secondary winemaking products" are examined. Activities are aimed at reducing prime cost of winemaking products due to the complex processing of secondary raw materials, which makes it possible to obtain products that are of considerable value for a number of national economy sectors, namely: ethyl alcohol, tartaric acid, enotanin, grape butter, vitamin B bioconcentrates, vitamin $D$, fodder feed, abrasive materials and others. A rational for Odessa region processing technique is presented, which includes new models of equipment - a separator, a crusher, an infra-red dryer. Means of raw materials heat treatment and equipment designs are protected by Ukrainian patents. According to the proposed methods of heat treatment, the IKS-1 dryer provides infrared heating of grape seeds with its subsequent adiabatic cooling-maturation. Dryer design diagram is provided. Technical implementation of infrared dryer automatic control system is examined as well in MatLab/Simulink environment, namely: control algorithms which ensure high accuracy of maintaining the temperature of the seeds during drying. The model of the dryer as a control object is presented, the structure of the system is proposed, which allows partial compensation of the external uncontrollable disturbances influences on the seeds temperature. Conventional and increased dynamic accuracy automatic control systems comparative simulation results are shown, which confirmed the expediency of inclusion an additional channel of external disturbances compensation. The results of industrial testing of equipment and automation systems are presented. The rational parameters of grape seeds drying technological process are revealed. The tryouts confirmed the claimed characteristics of the developed automatic control systems and equipment. 
Ключові слова: схема переробки виноградних вичавків, інфрачервона сушарка, система автоматичного регулювання з компенсацією зовнішніх збурень

Keywords: grape cake recycling scheme, infrared dryer, automatic control system with compensation of external disturbances

\section{Вступ}

Інтеграція України і Молдови у світовий економічний простір супроводжується жорсткою конкуренцією на ринку вина, що обумовлює необхідність підвищення якості виноробної продукції та зниження їі собівартості [1]. Істотним резервом зниження собівартості вина в Україні $\epsilon$ ефективне використання винограду шляхом впровадження безвідхідних технологій, яке розглядається як стратегічний напрямок раціонального використання обмежених природних ресурсів і охорони навколишнього середовища.

При переробці винограду на виноматеріали утворюється 15...20 \% вторинної сировини, раціональна переробка якої дає можливість одержувати продукти, що представляють значну цінність для ряду галузей народного господарства. Такими є: етиловий спирт, винна кислота, енотанин, виноградне масло, біоконцентрати вітамінів групи B, вітамін D, фуражні корми, абразивні матеріали та безліч інших.

3 метою вирішення існуючих проблем, пов'язаних з переробкою вторинної сировини виноробства, почався процес об'єднання виноробних підприємств на основі кластерної ідеології.

В 2017 р. Європейським союзом Україні та Молдові було виділене фінансування для реалізації грантового проекту ЄС № 83263440 «Розвиток українсько-молдавського транскордонного виробничо-науково-освітнього кластера по переробці вторинних продуктів виноробства».

Партнерами грантового проекту є:

o Ц Центр регіонального розвитку «Stabilitatea» (Комрат, Молдова) - лідируючий партнер;

o ГО «Центр міського розвитку та інформаційних технологій» (Одеса, Україна);

o Асоціація «Виноградарі і винороби Одеської області» (Одеса, Україна).

Асоційовані партнери:

о У Українська корпорація по виноградарству та виноробної промисловості «Укрвинпром» (Київ, Україна);

о Одеська національна академія харчових технологій (Одеса, Україна);

o Інститут проблем ринку і економіко-екологічних досліджень НАНУ (Одеса, Україна);

о Національний науковий центр «Інститут виноградарства і виноробства ім. В.Є. Таїрова» (Одеса, Україна).

\section{Аналіз літературних даних і постановка проблеми}

Анатомічні особливості виноградних ягід, а також сучасні ощадливі технології їх переробки на виноматеріали обумовлюють те, що вторинна сировина виноробства по змісту біологічно активних речовин перевершує вихідну сировину і вино. При раціональній її переробці можна одержати продукти, які представляють значну цінність для ряду галузей промисловості: харчової, фармацевтичної, парфюмерно-косметичної та ін.

Приклади продуктів переробки вторинної сировини виноробства наведені в таблиці 1.

Таблиця 1 - Продукти переробки вторинної сировини виноробства

\begin{tabular}{|c|c|}
\hline $\begin{array}{l}\text { Вторинна сировина } \\
\text { виноробства }\end{array}$ & $\begin{array}{l}\text { Продукти переробки вторинної сировини виноробства } \\
\text { (концентрація корисних речовин у вихідній сировині) }\end{array}$ \\
\hline Гребені & Енотанин (0,22...2,5\%), винна кислота, напої, добрива \\
\hline Вичавки & Етиловий спирт, винна кислота, вуглеводи, поліфенольні концентрати, напої \\
\hline Насіння & $\begin{array}{c}\text { Виноградне масло, (9,9...17,9 \%), вітамін D, корм для тварин, харчовий } \\
\text { порошок, абразивні матеріали, енотанин }(0,31 \ldots 5,6 \text { \%), білок }(8,2 \text { \%) }\end{array}$ \\
\hline Шкірочка & Поліфенольні концентрати, енотанин (0,15...4,2 \%), корм для тварин, добрива \\
\hline Дріжджові опади & $\begin{array}{c}\text { Спирт, біоконцентрати вітамінів групи В, білки, пептиди, амінокислоти, } \\
\text { енантовий ефір }\end{array}$ \\
\hline
\end{tabular}

Найбільшу частку і значимість серед вторинної сировини виноробства становлять виноградні вичавки, переробка яких є не вирішеною проблемою, над якою працює наш колектив.

Раціональна схема переробки виноградних вичавків

Вичавки - це щільний залишок твердих частин виноградного грона, який одержують після пресування солодкої або збродженої мезги.

У зв'язку зі швидким окисненням і мікробіальним псуванням цієї сировини необхідний їі поділ і сушіння, що забезпечує тривале зберігання, часто - до одного року. 
Закордонне технологічне устаткування для цієї мети досить витратне в придбанні та обслуговуванні. Це обмежує його застосування і ставить задачу розробки бюджетного вітчизняного автоматизованого устаткування, що не поступається по якості існуючим закордонним аналогам.

На першому етапі нами розроблені та виготовлені дослідно-промислові зразки устаткування, необхідного для первинної переробки виноградних вичавків. Це дозволило запропонувати раціональну для Одеського регіону технологічну схему, представлену на рис. 1. Вологі вичавки після виноградного преса переробного підприємства, наприклад, транспортером (стрічковим, шнековим або іншим) направляють у прийомний бункер розробленого нами сепаратора виноградних насіння СВС-2 продуктивністю 1000...1200 кг/год.

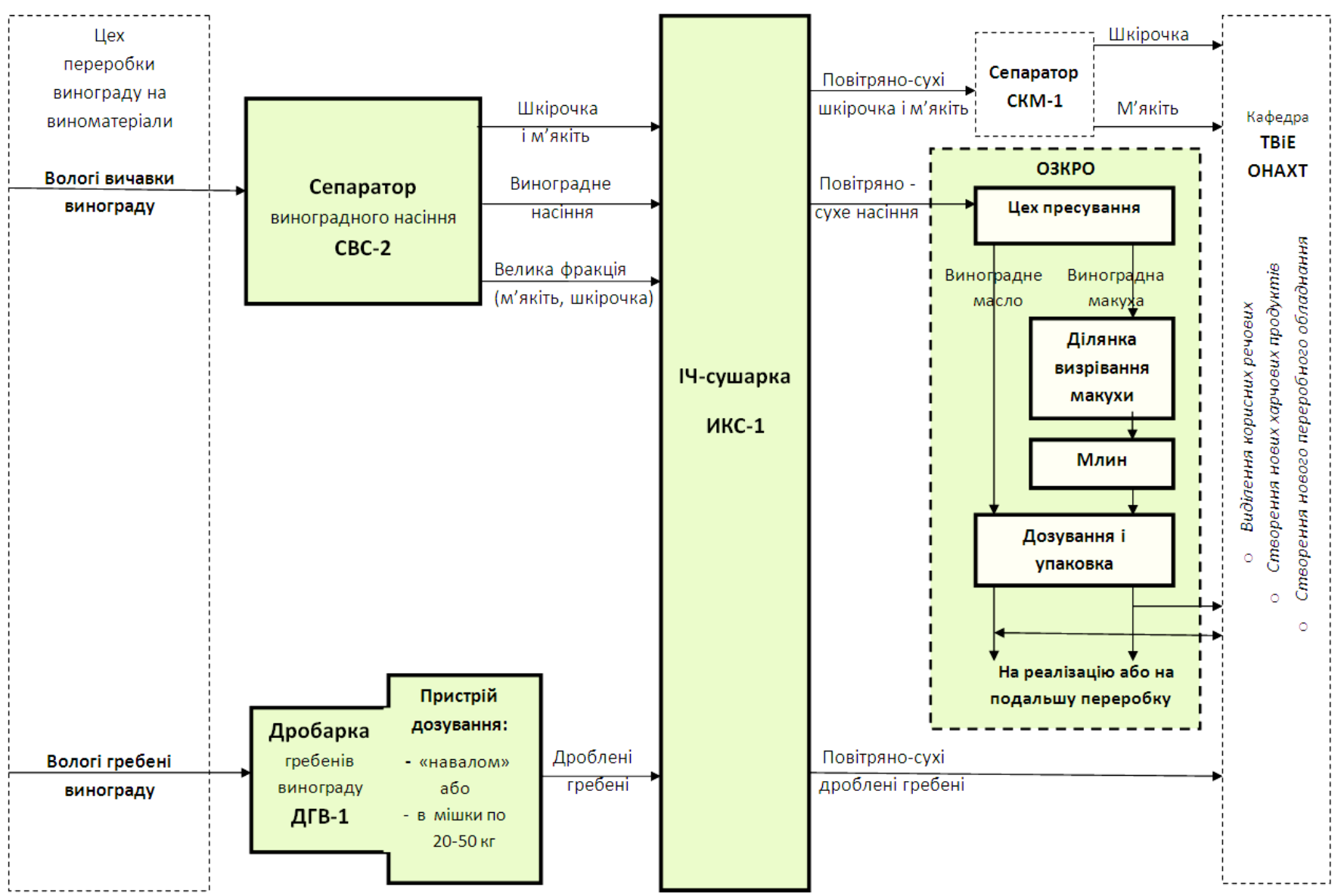

Рис. 1 - Схема переробки виноградних вичавків і гребенів

Тут вичавки піддають 2-х східчастому механічному впливу. На першому етапі відбувається розпушення грудок вичавків і відділення насіння винограду від його шкірочки і м'якоті. Потім усю масу просівають, розділяючи на три потоки: каліброваного насіння, шкірочки з м'якоттю і великих часток м'якоті із дрібним насінням, не придатним для одержання виноградного масла.

Оскільки отримані складові не підлягають тривалому зберіганню, їх максимально швидко направляють на сушіння, наприклад, у розробленій нами інфрачервоній сушарці ИКС-1 продуктивністю 300 ...350 кг/год.

Дослідно-промисловий зразок сушарки ИКС-1 дозволяє висушувати насіння винограду, шкірочку і м'якоть, які можна після цього зберігати тривалий час до початку їх переробки.

Переробка виноградного насіння передбачає виділення пресуванням виноградного масла, його фільтрацію, зберігання, дозування та бутелювання на Одеському заводі кісточкових і рослинних олій (ОЗКРО). При цьому частина виноградного масла направляють на подальшу переробку.

Виноградну макуху, отриману у результаті пресування, розмелюють на спеціальному млині [2], а отриманий порошок використовують, наприклад, для одержання какао-замінника, скрабів у косметиці та ін.

Висушена шкірочка винограду легко відділяється від його м'якоті шляхом повітряного сепарування в сепараторі CKM-1, який у цей час проходить випробування.

Суха шкірочка винограду використовується для одержання напоїв, наприклад, чаю типу «Каркаде». 
Гребені винограду характеризуються великою об'ємністю при малій масі, що вимагає їхнього здрібнювання та упакування в тару по місці одержання перед транспортуванням для подальшої переробки. Це зажадало розробки дробарки гребенів винограду ДГВ-1 продуктивністю 250...300 кг/год.

Створення нових харчових і інших продуктів

В даний час на кафедрі технології вина і енології (ТВіЕ) ОНАХТ проводяться дослідження з метою виділення корисних речовин і розробки нових харчових і інших продуктів із вторинної сировини виноробства. Зокрема, 3 висушених м'якоті, шкірочки і гребенів винограду.

\section{Мета і завдання дослідження}

Виробники сучасного устаткування оснащують його засобами автоматизації, які забезпечують задані номінальні режими роботи, зниження кількості браку і енерговитрат. У даній публікації розглянуте питання розробки системи автоматичного керування одного з видів устаткування, а саме інфрачервоної (IЧ) сушарка ИКС-1, розробленої нами для переробки вторинної сировини виноробства.

\section{Методи і матеріали дослідження}

Інфрачервона сушарка ИКС-1 як об'єкт керування

Інфрачервона сушарка ИКС-1, наведена на рис. 2, призначена для сушіння виноградного насіння перед виділенням з нього масла. Встановлена електрична потужність становить 30 кВт, продуктивність 300...350 кг/год.

Згідно із запропонованими способами термообробки [3, 4] сушарка ИКС-1 [5] забезпечує інфрачервоне нагрівання 3 наступним адіабатичним охолодженням-дозріванням насіння у зоні розрідження.

У корпусі 1 сушарки передбачені регулювальні болти 2, за допомогою яких можна змінювати нахил (продуктивність) ИКС-1. Там же змонтований вібротранспортер насіння, який складається 3 полотна 3 і сита 4, що представляють собою єдину жорстку конструкцію. Електропривод 5 за допомогою штовхача 6 і шатунів 7 здійснює зворотно-поступальний рух вібротранспортера, переміщаючи оброблюване виноградне насіння.

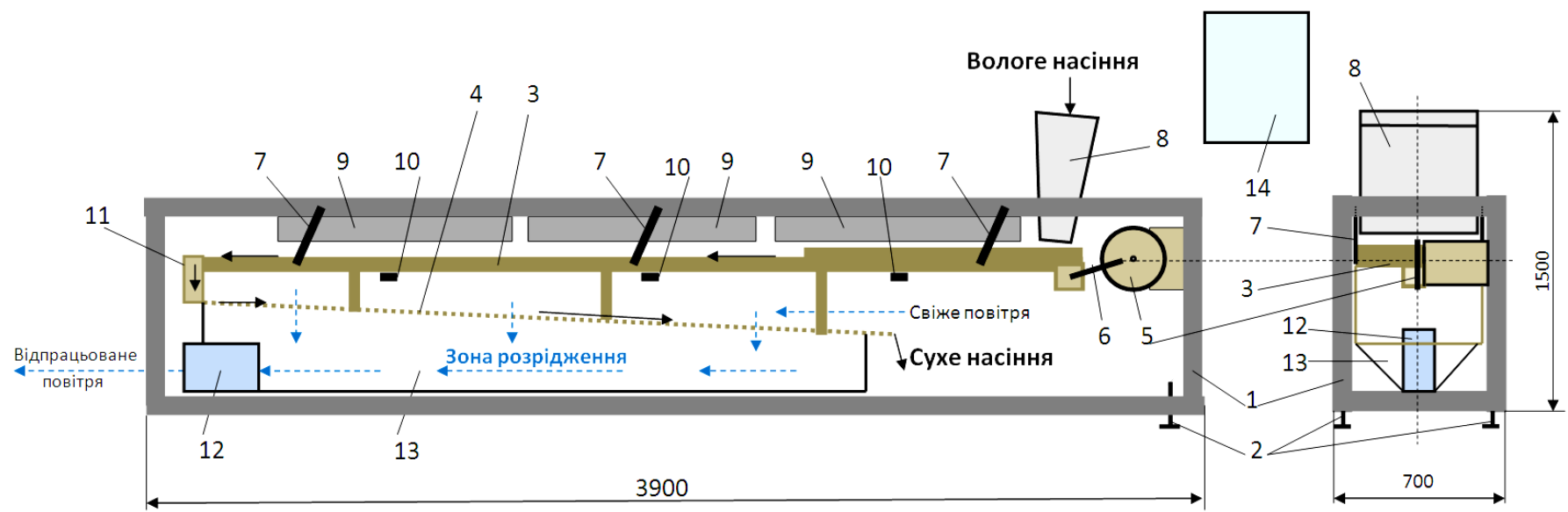

1 - корпус сушарки; 2 - регулювальні болти; 3 - полотно віибротранспортера (зона ІЧ-нагрівання); 4 - сито вібротранспортера (зона адіабатичного охолодження-дозрівання); 5 - електропривод вібротранспортера;

6 - штовхач; 7 - шатуни; 8 - завантажувальний бункер; 9 - IЧ-нагрівачі; 10 - ПП температури полотна вібротранспортера; 11 - пристрій контролю середньої температури насіння; 12 - вентилятор; 13 - кожух зони розрідження; 14 - щит контролю і керування.

\section{Рис. 2 - Загальний вид інфрачервоної сушарки виноградного насіння ИКС-1}

Для завантаження насіння у сушарку передбачений завантажувальний бункер 8, обладнаний регулювальною заслінкою і пристроєм рівномірного розподілу насіння по полотну 3.

Над цим полотном у трьох зонах нагрівання насіння встановлені ІЧ-нагрівачі 9. Контроль температури полотна 3 у цих зонах (зі зворотної сторони цього полотна) здійснюють за допомогою первинних вимірювальних перетворювачів (ПП) температури 10, у якості яких застосовані поверхневі термометри опору градуювання 100П класу допуску «В».

Середню температуру потоку насіння після нагрівання контролюють пристроєм 11, який сповільнює проходження насіння із полотна 3 самопливом на сито 4 зони охолодження. У пристрої 11 насіння направляють до встановлених тут термометрів опору градуювання 100 П класу допуску «В», оснащених радіаторами для ефективного теплообміну 3 потоком насіння. Ці термометри, підключені до мікропроцесорного контролера, вимірюють середню температуру в

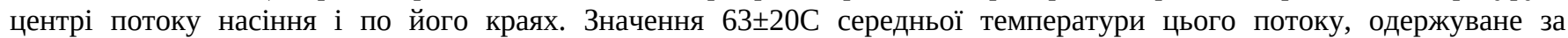
допомогою пристрою 11, свідчить про задане значення його кондиційної вологості. 
Після пристрою 11, насіння попадає на сито 4 - у зону охолодження, де прохолоджуються за рахунок теплообміну з атмосферним повітрям, що всмоктується вентилятором 12 крізь сито 4. При цьому зона розрідження 13 поєднує піддон сита 4 із всмоктувальним патрубком вентилятора 4.

Мікропроцесорна та інша контрольно-вимірювальна апаратура, що здійснює контроль процесу сушіння, змонтована в щиті контролю і керування 14. Щит настінного виконання $з$ передніми дверми, має габарити 400x400x200 мм.

Перша і друга (по ходу руху насіння) зони теплової ІЧ-обробки не регульовані. Електрична потужність останньої третьої зони нагрівання регулюється за допомогою мікроконтролера і симісторного перетворювача по сигналу ПП усередненої температури потоку насіння, який змонтовано в пристрої 11.

Структурна схема даного об'єкта керування (ОК), має вигляд, наведений на рис. 3.

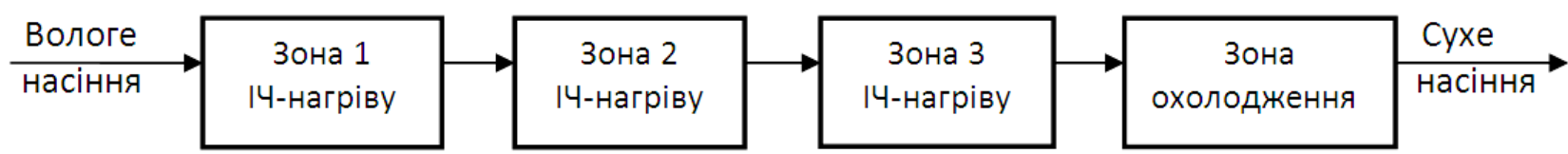

Рис. 3 - Структурна схема сушарки як об'єкта керування

Дослідження системи автоматичного регулювання сушарки ИКС-1

Структурна схема, наведена на рис. 4, відбиває матеріальні потоки і інформаційні зв'язки в системі. ПП температури сушарки пов'язані 3 мікропроцесорним контролером, який виробляє сигнали керування, що включають/відключають вібротранспортер, вентилятор, ІЧ-нагрівачі першої і другий зон нагрівання. Контролер, крім того, за допомогою симісторного перетворювача змінює електричну потужність ІЧ-нагрівача третьої зони нагрівання, виводячи середню кінцеву температуру потоку насіння після зон нагрівання на задане значення і стабілізуючи його.

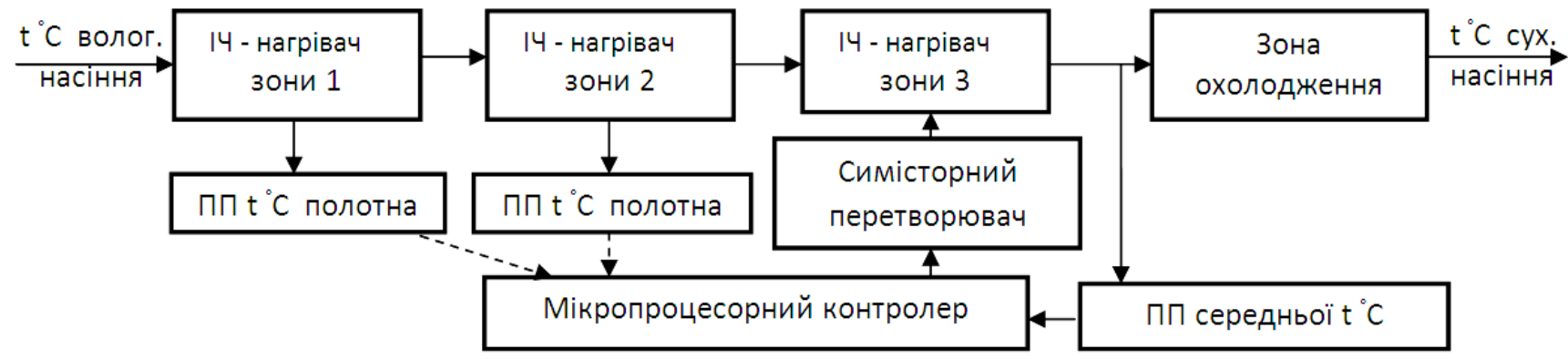

Рис. 4 - Технічна структура системи автоматичного регулювання сушарки ИКС-1

У процесі функціонування на систему автоматичного регулювання (САР) сушарки впливають збурення, викликані відхиленням температур навколишнього середовища і вологості насіння на вході в сушарку, маси і швидкості переміщення насіння по вібротранспортеру, коливання напруги в мережі живлення та інші зовнішні фактори. Дія збурень збільшує час виходу на номінальний режим роботи сушарки і погіршують якість стабілізації температури насіння на виході, що часто приводить до неприпустимих коливань його кінцевої вологості.

Це визначило необхідність дослідження і розробки в рамках наведеної структури САР раціональних алгоритмів регулювання.

Дослідження системи проводилося шляхом комп'ютерного імітаційного моделювання CAP у середовищі Simulink пакета програм Matlab. На схемі моделювання, наведеної на рис. 5, значення керуючих впливів $\mathrm{u}_{1}(\mathrm{t}), \mathrm{u}_{2}(\mathrm{t}), \mathrm{u}_{3}(\mathrm{t})$ прийняті в діапазоні зміни $0 . .100$ \%. Вони подаються на ІЧ-нагрівачі $\mathrm{N}_{1}, \mathrm{~N}_{2}, \mathrm{~N}_{3}$, представлені безінерційними ланками 3 коефіцієнтами передачі $\mathrm{k}_{1}, \mathrm{k}_{2}, \mathrm{k}_{3},{ }^{\circ} 3 / \%$. У результаті нагрівання відбувається зміна температур насіння $\mathrm{y}_{1}(\mathrm{t}), \mathrm{y}_{2}(\mathrm{t}) \mathrm{i}$ $\mathrm{y}_{3}(\mathrm{t}){ }^{\circ} \mathrm{C}$ на виході відповідно зон 1,2 і 3. Динаміка зон представлена передатними функціями $W=\exp \left(\tau_{i}\right) /\left(T_{i} p+1\right)^{2}$, які з достатньої для практичних цілей точністю описують процес нагрівання. Зовнішні неконтрольовані збурення $\mathrm{f}_{1}(\mathrm{t})$, $\mathrm{f}_{2}(\mathrm{t}), \mathrm{f}_{3}(\mathrm{t})$ відбивають вплив на процес нагрівання зовнішніх факторів, у моделі вони приведені до входів у зонах нагрівання i їх вплив виражається в ${ }^{\circ} \mathrm{C}$. При цьому слід зазначити, що інтенсивність збурення $\mathrm{f}_{1}(\mathrm{t})$ найбільша, оскільки воно пов'язане з нерівномірністю початкової вологості насіння на вході і нерівномірністю його подачі. 


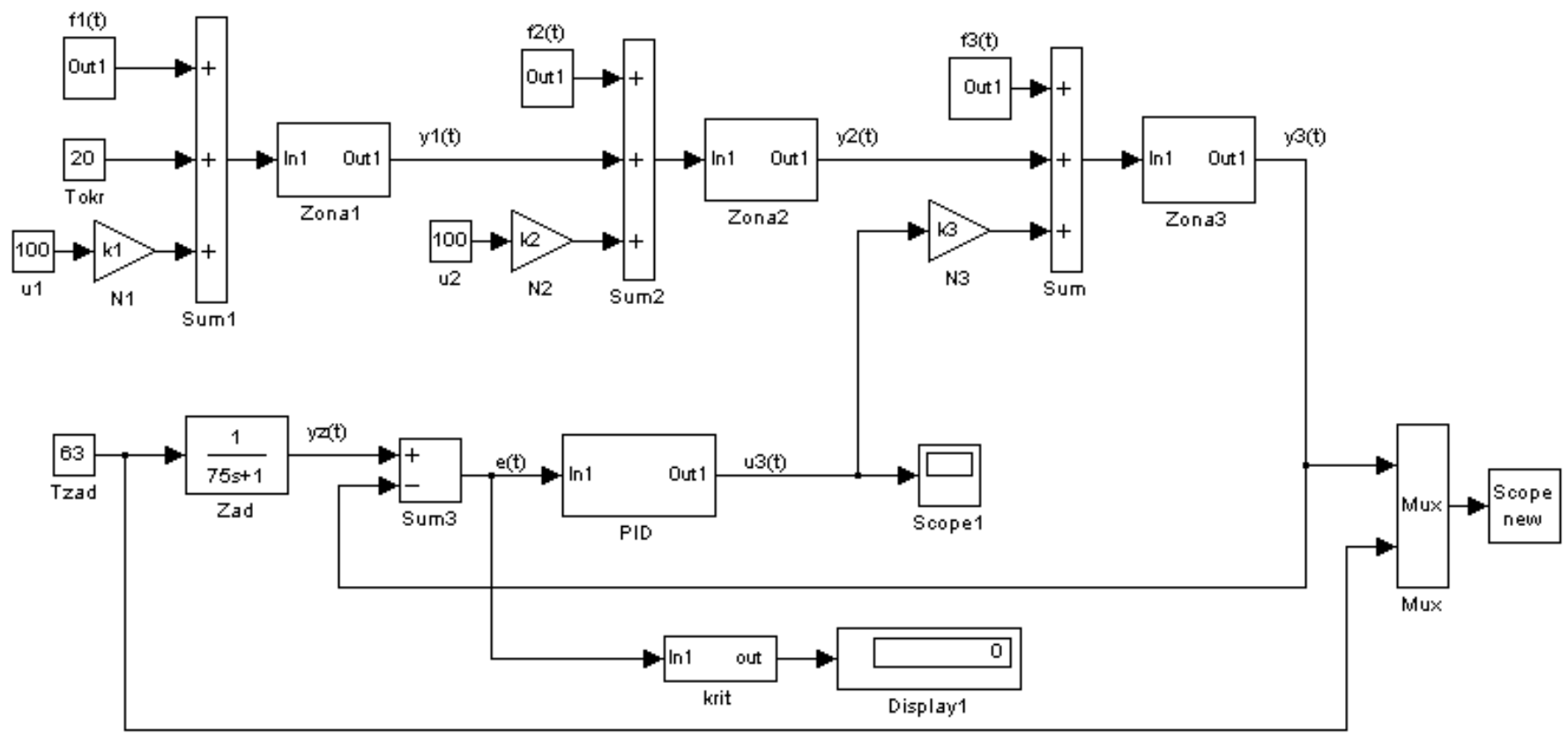

Рис. 5 - Схема моделювання САР сушарки ИКС-1 найпростішої структури

САР найпростішої структури, яку звичайно обирають для простих об'єктів керування, являє собою одноконтурну систему з ПІД-регулятором. У цьому випадку регулятор стабілізує температуру насіння на виході із третьої зони на значенні $\mathrm{t}_{\text {зад }}=63{ }^{\circ} \mathrm{C}$, змінюючи потужність нагрівача $\mathrm{N} 3$. Якість регулювання може бути оцінена, наприклад, за критерієм

$$
I=\frac{1}{T_{\bmod }} \int_{0}^{T_{\bmod }}|e(t)| d t, \rightarrow \min ,
$$

де $\mathrm{T}_{\text {mod }}$ - час моделювання, $\mathrm{e}(\mathrm{t})$ - помилка регулювання, яка дорівнює різниці між поточним значенням регульованої температури і заданим.

В процесі експлуатації на САР безупинно впливають неконтрольовані виробничі збурення, що приводять до погіршення якості її роботи.

Частково компенсувати вплив, наприклад, збурення $\mathrm{f}_{1}(\mathrm{t})$ на регульовану змінну - температуру в третій зоні можна при використанні САР з компенсацією збурень.

Оскільки температура полотна вібротранспортера на виході з першої зони вимірюється, то можна при цьому побудувати додатковий канал зв'язку, який буде коректувати керуючий вплив регулятора, поліпшуючи якість регулювання. Із цією метою була складена структурна схема САР з компенсацією збурення, наведена на рис.6.

При цьому слід зазначити, що необхідною умовою використання даної структури є адекватність моделей першої і другої зон нагрівання їх реальним динамічним властивостям. Із цією метою на дослідно-промисловому зразку сушарки ИКС-1 були експериментально визначені перехідні характеристики зон нагрівання, а по отриманих при цьому результатам побудовані відповідні моделі. У процесі дослідно-промислової експлуатації сушарки в 2017 р. було зроблене припущення, що для зниження коливань при пуску системи задатчик у даній САР повинен бути інерційним (блок Zad на рис.6) з передатною функцією

$$
W(p)=1 /\left(5 * T_{i} p+1\right) \text {. }
$$

\section{Результати досліджень}

При параметричному синтезі раціональної САР було проведено комп'ютерне моделювання системи в різних режимах її роботи. Деякі з результатів наведені в даній публікації.

На рис. 7а показані динамічні характеристики зон нагрівання сушарки ИКС-1 як об'єктів керування, а також фрагменти сталих режимів з коливаннями кінцевої температури нагрівання насіння під впливом збурень. 


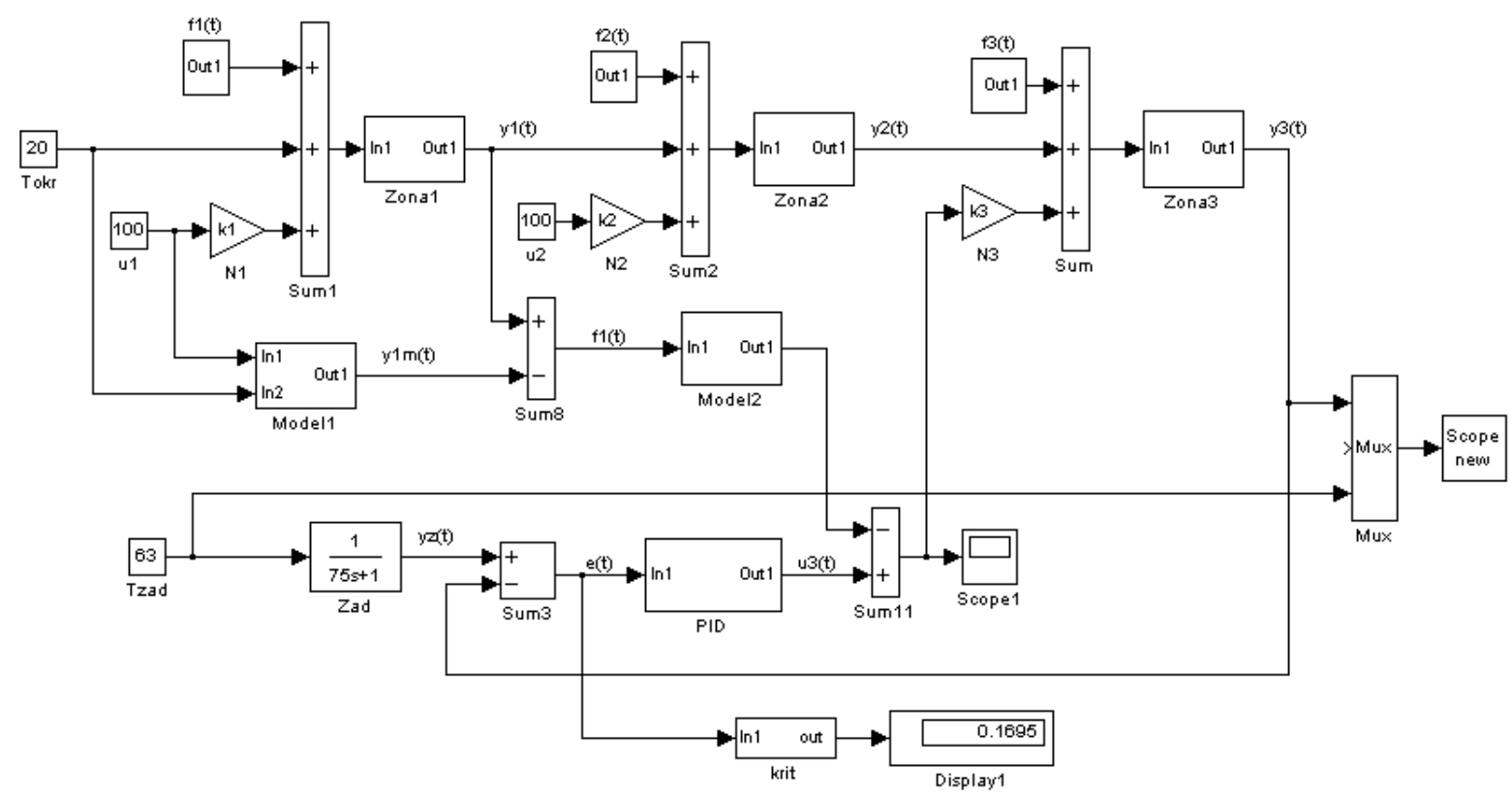

a)

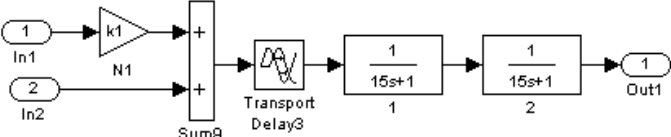

б)

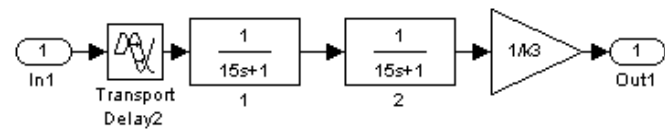

в)

а) схема моделювання з компенсацією зовнішнього збурення $f_{1}(t)$;

б) схема моделі першої зони нагрівання (Model 1);

в) схема моделі другої зони нагрівання (Model 2)

Рис. 6 - Схеми моделювання САР $з$ компенсацією збурень

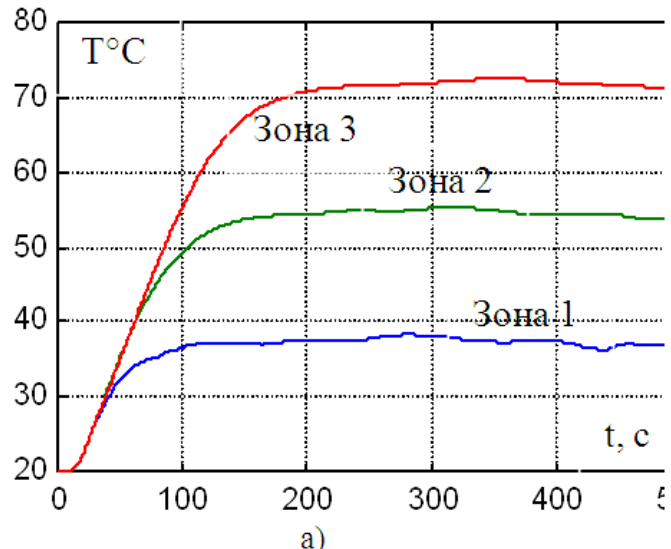

a)

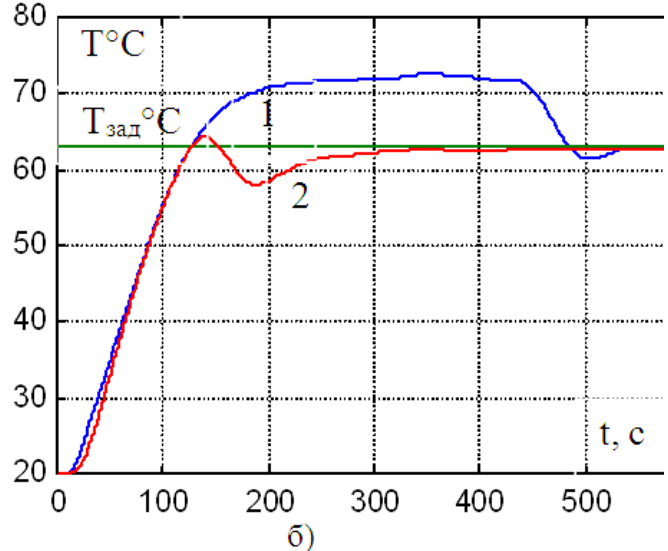

б)

a) - перехідні та сталі процеси в ОК;

б) - пускові режими САР: 1 - з безінерционим задатчиком; 2 - з інерційним задатчиком

Рис.7 - Результати комп'ютерних експериментів

Результати моделювання САР, наведені на рис. 7б, підтверджують доцільність прийнятого припущення про застосування інерційного задатчика. При цьому час виходу на режим і коливання температури при пуску системи, які викликані запізненням у контурі регулювання і обмеженням керуючого впливу регулятора, знижуються. 
Деякі результати порівняльного дослідження різних САР при дії випадкових збурень наведені на рис. 8.

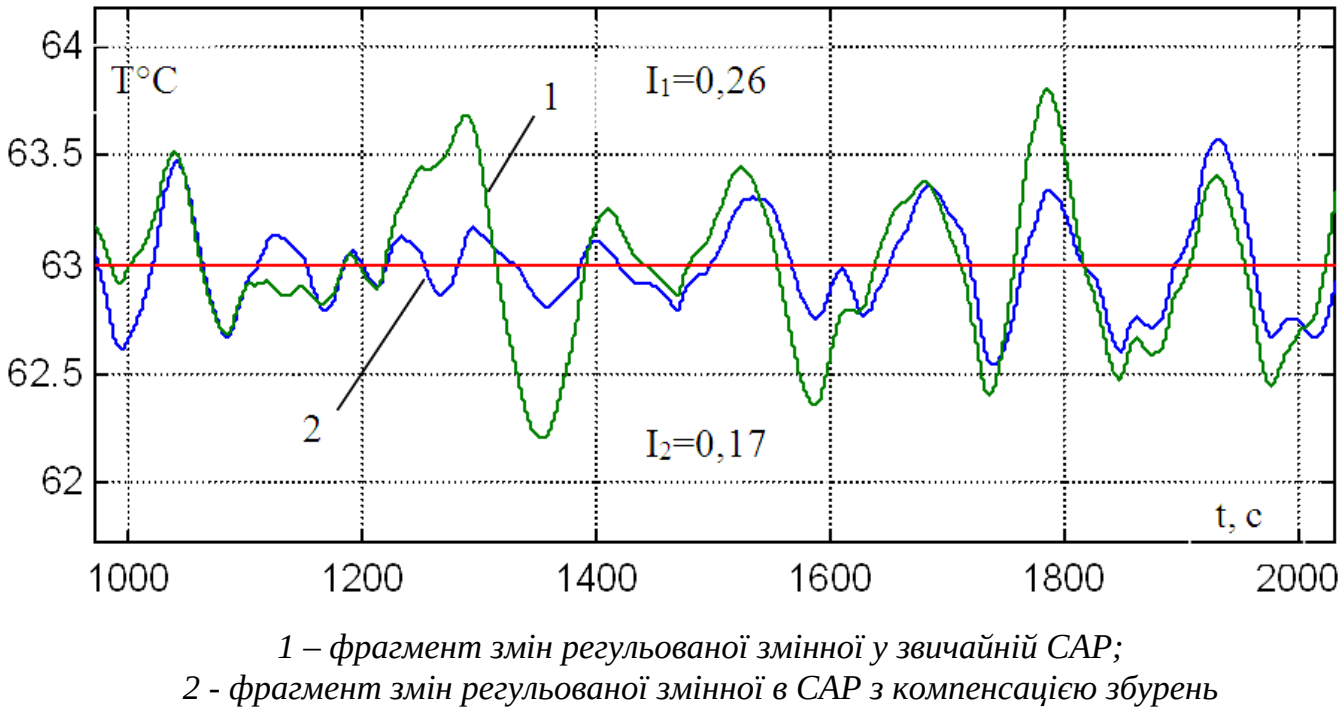

Рис. 8 - Порівняльні результати моделювання САР

Використання запропонованої структури САР 3 компенсацією впливу збурення $\mathrm{f}_{1}(\mathrm{t})$ за інших рівних умов дозволило знизити (крива 2) амплітуди коливань і значення критерію якості регулювання. Дана структура САР може бути ефективно використана на практиці.

Реалізація запропонованої САР може бути легко здійснена програмним шляхом з використанням вітчизняного мікропроцесорного контролера, наприклад, типу МІК-52 фірми «Мікрол».

Випробування розроблених систем і устаткування

3 метою перевірки ефективності запропонованих нами рішень були виготовлені зменшені фізичні моделі устаткування для первинної переробки вторинної сировини виноробства.

Восени 2017 р. ці моделі були піддані випробуванням на Одеському заводі кісточкових і рослинних олій. Успішність випробувань відкрила дорогу подальшому вдосконалюванню наших розробок. У наслідку були виготовлені і дослідно-промислові зразки устаткування, які також пройшли випробування на ОЗКРО.

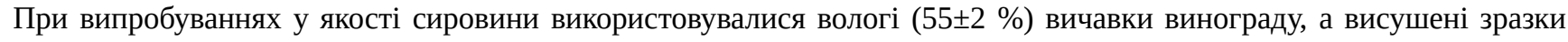
насіння, шкірочки, порошку з макухи насіння оцінювали згідно зі стандартними методиками $[6,7,8]$.

Досліджувалися різні режими роботи устаткування, вплив ряду факторів, серед яких зміни маси і швидкості руху сировини в зонах обробки, кількості проходів сировини, температурні режими та ін.

Так, наприклад, при дослідженні дослідно-промислового зразка інфрачервоної сушарки виноградного насіння ИКС-1 було встановлено, що значення середньої кінцевої температури насіння $63 \pm 2{ }^{\circ} \mathrm{C}$ після ІЧ-нагрівання відповідає значенню 8-10 \% вологості на виході із сушарки, а «час перебування» у зонах сушіння при цьому становить близько 2 хвилин.

Восени 2018 р. розроблені нами дослідно-промислові зразки устаткування пройшли «польові випробування» у господарстві « Фрумушика-Нова» Тарутинского району Одеської області (рис. 9).

Сепаратор виноградного насіння CBC-2, IЧ-сушарка IKC-1 і дробарка виноградних гребенів ДГВ-2 були змонтовані на відкритому майданчику господарства і використовувалися для первинної переробки виноградних вичавків і гребенів, що надходили з місцевого винзаводу.

Отримані при цьому напівфабрикати послужили сировиною при їхній подальшій переробці відповідно розглянутій раніше схемі (див. рис. 1) на ОЗКРО.

У процесі експлуатації розробленого нами устаткування були виявлені та усунуті окремі недоліки, відпрацьована технологія його обслуговування. Зразки готових продуктів були піддані лабораторним аналізам.

У цілому випробування пройшли успішно, підтвердивши заявлені характеристики розроблених систем автоматизації і устаткування. 


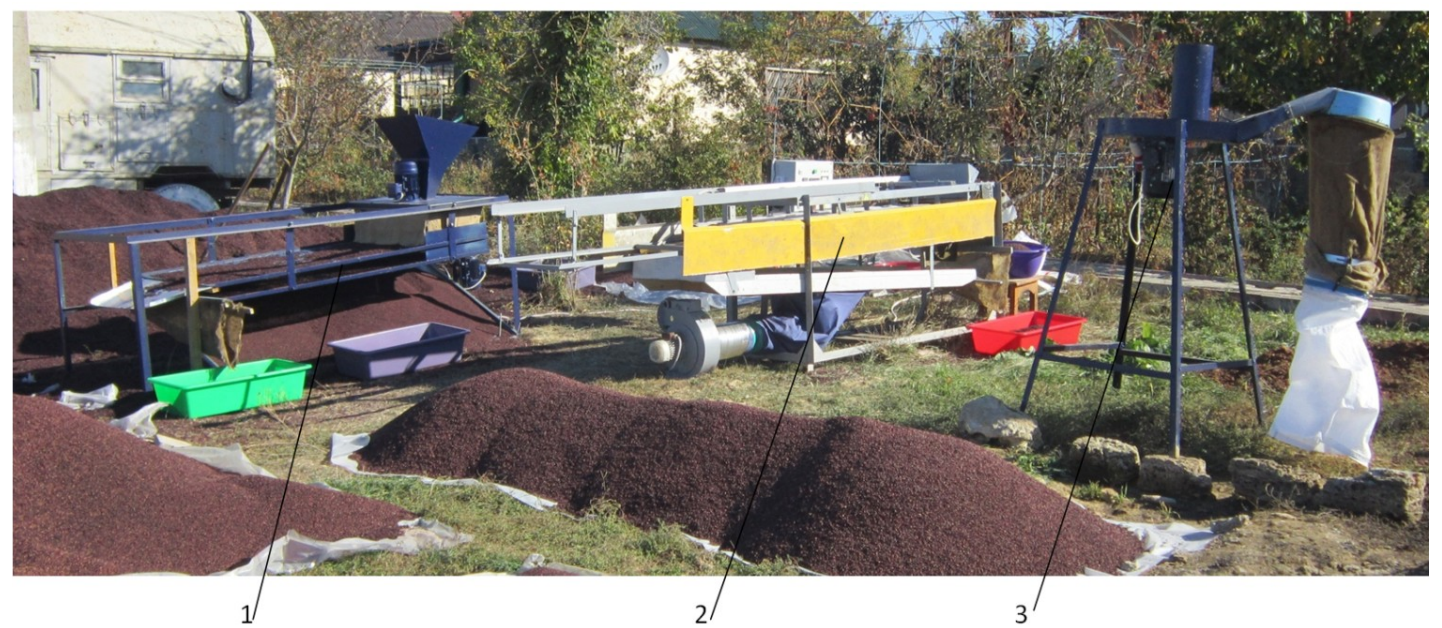

1 - сепаратор виноградного насіння СВС-2; 2 - інфрачервона сушарка ИКС-1;

3 - дробарка гребенів винограду ДГВ-2.

\section{Рис. 9 - Випробування розробленого устаткування в господарстві «Фрумушика-Нова»}

\section{Висновки}

1. Переробка вторинної сировини виноробства $є$ важливим народногосподарським завданням.

2. Розроблена раціональна для Одеського регіону технологічна схема переробки виноградних вичавків i гребенів.

3. Розроблений і виготовлений ряд дослідно-промислових зразків устаткування для реалізації цієї технологічної схеми.

4. Розроблена, досліджена, змонтована і налагоджена САР інфрачервоної сушарки виноградного насіння.

5. Проведені успішні випробування розроблених зразків систем і устаткування в лабораторних і заводських умовах на Одеському заводі кісточкових і рослинних олій, а також в «польових умовах» агрогосподарства « Фрумушика-Нова».

6. Комплекс розробленого вітчизняного устаткування може бути рекомендований для ефективної переробки вторинної сировини виноробства в Україні і Молдові.

\section{Список використаних джерел}

[1] Концептуальное и экономическое обоснование эффективности кластерного подхода к переработке вторичного сырья виноделия / В.Н. Осипов, Л.А.Осипова, О.А. Ермакова и др.; Проект «Развитие украинско-молдавского приграничного производственно-научно-образовательного кластера по переработке вторичных продуктов виноделия», German Coop., Территориальное сотрудничество стран Восточного партнерства. Кишинеу: Воns Offices, 2018. 36 c.

[2] Спосіб автоматично керованого подрібнення макухи олійних культур та пристрій для його здійснення: пат. 77864 Україна: МПК(2006) В02С 9/00, В02С 25/00. № а200504070; заявл. 28.04.2005; опубл. 15.01.2007, Бюл. № 1.

[3] Спосіб автоматично керованої термообробки зерна: пат. 89433 Україна: МПК(2009) B02B 1/00, B02B 5/00, F26B 3/28, F26B 3/32, F26B 17/18. № a200804758; заявл. 14.04.2008; опубл. 26.10.2009, Бюл. №2.

[4] Спосіб автоматично керованого сушіння насіння: пат. 113670 Україна: МПК(2016) A23N 12/00, A23B 9/02 (2006), F26B 3/30 (2006), F26B 3/22 (2006). № а201505514; заявл. 04.06.2015; опубл. 27.02.2017, Бюл. № 4.

[5] Автоматична сушарка насіння: пат. 115077 Україна: МПК(2017) F26B 3/30 (2006), F26B 3/22 (2006), F26B 11/00, A23N 12/08 (2016), А23В 9/02 (2006). № а201505499; заявл. 04.06.2015; опубл. 11.09.2017, Бюл. № 17.

[6] ДСТУ 4811:2007. Насіння олійних культур: Методи визначення вологості. Київ: Держспоживстандарт України, 2008. 6 с. (Стандарт Держспоживстандарт України)

[7] ОСТ 10 108-88. Семена виноградные для промышленной переработки: Технические условия. Москва: Министерство сельского хозяйства, 1988. 7 с.

[8] СОУ 15.3-37-091:2004. Порошок з макухи насіння винограду: Технічні умови. Київ: Мінагрополітики України, 2004. 12 с. (Стандарт Мінагрополітики України)

\section{References}

[1] V. Osipov, L. Osipova and O. Ermakova, "Kontseptualnoe i ekonomicheskoe obosnovanie effektivnosti klasternogo podhoda $\mathrm{k}$ pererabotke vtorichnogo syirya vinodeliya", «Razvitie ukrainsko-moldavskogo prigranichnogo proizvodstvenno-nauchno-obrazovatelnogo klastera po pererabotke vtorichnyih produktov vinodeliya», p. $36,2018$. 
[2] "Sposib avtomatichno kerovanogo podribnennya makuhi oliynih kultur ta pristriy dlya yogo zdiysnennya", UA 77864, 2007.

[3] "Sposib avtomatichno kerovanoyi termoobrobki zerna", UA 89433, 2009.

[4] "Sposib avtomatichno kerovanogo sushinnya nasinnya", UA 113670, 2017.

[5] "Avtomatichna susharka nasinnya", UA 115077, 2017.

[6] DSTU 4811:2007, "Nasinnya oliynih kultur: Metodi viznachennya vologosti", Standart Derzhspozhivstandart Ukrayini, Kiyiv, 2008.

[7] OST 10 108-88, "Semena vinogradnyie dlya promyishlennoy pererabotki: Tehnicheskie usloviya", Ministerstvo selskogo hozyaystva, Moskva, 1988.

[8] SOU 15.3-37-091:2004, "Poroshok z makuhi nasInnya vinogradu: Tehnichni umovi", Minagropolitiki Ukrayini, Kiyiv, 2004.

UDC 18:011.56:502.33

\title{
FEATURES OF THE TECHNICAL OBJECTS CONTROL WITH REGISTRATION THEIR WEAR-OUT
}

\author{
Voinova S.A. \\ Odessa National Academy of Food Technologies, Odessa \\ ORCID: 0000-0003-0203-0599 \\ E-mail: voinova_s@yahoo.com
}

Copyright (C) 2018 by author and the journal "Automation technologies and business - processes. This work is licensed under the Creative Commons Attribution International License (CC BY). http://creativecommons.org/licanses/by/4.0

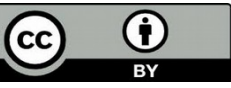

ONAFT

Open Access

DOI: $10.15673 /$ atbp.v10i4.1228

\begin{abstract}
The operation of technical objects is subject to the regulatory conditions established by their manufacturer. Regime of regulatory conditions keeping needs to be controlled. A new technical object at the time of commissioning has an initial, maximum level of technological efficiency of operation, including ecological, economic and general technical components, and has an initial, complete working capacity resource too. During operation, the technical object wears-out, its technological efficiency is reduced. In accordance with the international standard and the standard of Ukraine, a technical object that has exhausted a resource is subject to decommissioning and replacement with a new technical object, since at a level of technological efficiency that is less than the minimum, the use of technical object is inexpedient. However, in the current difficult economic conditions in Ukraine, the replacement of worn-out equipment with a new one is impracticable. Further use of worn-out equipment is inevitable. To control a worn out object, complex automation is required. The technical object is studied in this direction from three positions. The first is to study the process of wearing-out. The second is the prediction of wearing-out dynamics. The third is the object control in the process of its wearing-out. The development of the theory and practice of worn out objects automating leads to the formulation of new tasks. With long-term operation of the equipment, it is necessary to periodically adjust its characteristics. It is necessary to create adaptive automatic control systems that take into account the degree of equipment wear-out and conditions of its operation. It is important to establish the patterns of influence of the current state of the equipment and the operating conditions on its residual resource. A productive way to increase the efficiency of worn-out equipment is its renovation by implementing measures that increase the level of efficiency of the most worn-out elements of technical objects. The technical objects control with registration their wear-out will ensure compliance with the regulations for their operation.
\end{abstract}

Keywords: technical object, regulatory conditions, wear-out, control, technological efficiency, automation, renovation.

\section{Introduction}

The stagnant development of world production, which began in the middle of the last century and continues today, has led to a complication of its state. In Ukraine, as in other countries, in the fleet of operating equipment, the proportion of technical objects (TO) that have spent their working capacity resources has increased prohibitively. For example, in the most advanced 